\title{
Exposure to pastures fertilised with sewage sludge disrupts bone tissue homeostasis in sheep
}

\author{
P. Monica Lind ${ }^{a, *}$, Magnus Gustafsson ${ }^{b}$, Sanne A.B. Hermsen ${ }^{a}$, Sune Larsson ${ }^{c}$, \\ Carol E. Kyle ${ }^{d}$, Jan Örberg ${ }^{b}$, Stewart M. Rhind ${ }^{d}$ \\ ${ }^{a}$ Institute of Environmental Medicine, Karolinska Institutet, Stockholm, Sweden \\ ${ }^{b}$ Department of Environmental Toxicology, Uppsala University, Uppsala, Sweden \\ ${ }^{c}$ Department of Orthopaedics, University of Uppsala, Uppsala, Sweden \\ ${ }^{\mathrm{d}}$ Macaulay Institute, Craigiebuckler, Aberdeen AB15 8QH, UK
}

\section{A R T I C L E D A T A}

Article history:

Received 10 October 2008

Received in revised form

12 December 2008

Accepted 14 December 2008

Available online 21 January 2009

Keywords:

Sewage sludge

Bone toxicity

Sheep

pQCT

EDCs

\begin{abstract}
A B S T R A C T
The femurs of male and female sheep (Ovis aries), aged 18 months, bred on pastures fertilized twice annually with sewage sludge (2.25 tonnes dry matter/ha; Treated; T)) or on pastures treated with inorganic fertilizer (Control; C) were studied, using peripheral Quantitative Computed Tomography (PQCT) and the three-point bending test. Males were maintained on the respective treatments from conception to weaning and then maintained on control pastures while the females were maintained on the respective treatments until slaughter. $\mathrm{T}$ rams exhibited increased total bone mineral density (BMD) at the metaphyseal part of femur $(+10.5 \%, p<0.01)$ compared with $C$ rams but had a reduced total cross sectional area (CSA, $-11.5 \%, p<0.001)$, trabecular CSA $(-17.1 \%, p<0.01)$ and periosteal circumference $(-5.7 \%, p<0.001)$. In the mid-diaphyseal part, $\mathrm{T}$ rams had an increased total BMD $(+13.8 \%$, $p<0.0001)$ and stiffness $(+6.4 \%, p<0.01)$ but reduced total CSA $(-12.1 \%, p<0.0001)$ and marrow cavity $(-25.8 \%, p<0.0001)$, relative to $C$ rams.

In ewes although pQCT analysis of neither the metaphyseal nor the mid-diaphyseal part of the female femur bones showed any significant differences with treatment, the biomechanical method revealed a reduction in load at failure $(-17.3 \%, p<0.01)$ and stiffness $(-10.7 \%, p<0.05)$ amongst $\mathrm{T}$ ewes. It is concluded that exposure to pollutants present in sewage sludge can perturb bone tissue homeostasis in sheep, but particularly in males.
\end{abstract}

(c) 2008 Elsevier B.V. All rights reserved.

\section{Introduction}

The application of sewage sludge to land is likely to increase in both Europe and the United States as a dumping at sea is banned and land-fill sites become less available (Rhind et al., 2005b; Swanson et al., 2004). However, sludge contains high concentrations of many environmental pollutants including endocrine disrupting compounds (EDCs) such as alkyl phenols, phthalates, polychlorinated biphenyls (PCBs), polybro- minated diphenyl ethers (PBDE), polycyclic aromatic hydrocarbons (PAH), dioxins, pesticides and toxic metals (Brunner et al., 1988; Ghanem et al., 2007; Giger et al., 1984; Stevens et al., 2003). Since these are known to exert adverse effects on animal and human physiology and health (IEH, 1999; Toppari et al., 1996), potential effects on wildlife, domestic animals and humans are of concern.

Theoretical and empirical studies, designed to investigate the issue of accumulation of pollutants in domestic animal

\footnotetext{
* Corresponding author. Division of Biochemical Toxicology and Cancer Research, Institute of Environmental Medicine, Karolinska Institutet, Nobels väg 13, plan 3 Box 210, S-17177 Stockholm, Sweden. Tel.: +46 8524 87525; fax: +46 8343849.

E-mail address: Monica.Lind@ki.se (P.M. Lind).
} 
products, generally indicate that exposure to sewage sludge is associated with only limited tissue accumulation (Rhind, 2005; Rhind et al., 2005a; Rhind et al., 2005b; Smith, 1995) and so the risks to humans of exposure to pollutants through the consumption of animal products is likely to be small. On the other hand, previous studies of sheep grazing pastures fertilized with either sewage sludge or inorganic fertiliser have shown that exposure to EDCs and other pollutants through the sewage sludge can disrupt the development and function of the foetal testis (Paul et al., 2005), ovary (Fowler et al., 2008) and adult offspring behavior (Erhard and Rhind, 2004). These observations suggest that human health could be at risk, from exposure to environmental concentrations of a mixture of pollutants, not only through the application of sludges to land but also more generically, through routes other than the consumption of contaminated domestic animal products such as through diet or inhalation.

One significant human health issue is the reduction in bone formation at the tissue level (Seeman, 2008) associated with declining oestrogenic influence, particularly in postmenopausal women. Since many EDCs have oestrogenic effects, the potential significance of increasing exposure to environmental oestrogens with respect to bone density is of public health interest. Evidence of effects on bone structure of exposure to a range of pollutant classes has been derived, in part, from empirical studies designed to investigate effects of exposure and mechanisms of action using laboratory animals Hermsen et al., 2008; Jamsa et al., 2001; Lind et al., 1999; Lind et al., 2000b; Miettinen et al., 2005; Yilmaz et al., 2006) and domestic animals (Lundberg et al., 2006). Most of these studies concern exposure to abnormally high concentrations of the chemicals concerned. Studies of wildlife species (Fox et al., 2008; Lind et al., 2003; Lind et al., 2004; Sonne et al., 2004) and of humans (Alveblom et al., 2003; Glynn et al., 2000; Hodgson et al., 2008) based on observational data show effects of exposure but, owing to the fact that the populations studied have been exposed to a mixture of pollutants, cannot identify the causal agents.

The aim of this study was to study effects on bone tissue of rearing sheep on pastures fertilized with sewage sludge so that they were exposed to a mixture of organic pollutants and heavy metals, for a prolonged period, but at concentrations that were only slightly elevated relative to background. In view of the different circulating steroid profiles of male and female animals, both sexes were studied. However, owing to the fact that male and female animals could not be maintained on the same pastures, to avoid uncontrolled matings and requirements of other components of the experimental programme, it was not possible to treat the two sexes identically. Thus, the groups of male and female animals were regarded as two separate experiments and could not be directly compared, in the statistical analysis.

\section{Material and methods}

All animal procedures were approved by the ethical committee of the Macaulay Institute.

\subsection{Animals and exposure}

Two groups of Texel ewes (Ovis aries) were mated with Texel rams on pastures fertilized with sewage sludge (Treated; T) or inorganic fertilizer (Control; C), at the Macaulay Institute's Research Station in Hartwood, Scotland. The patterns of sludge and fertilizer application have been described previously (Rhind et al., 2002). Briefly, the $T$ pastures were fertilized by surface application of thermally-dried pellets of sewage sludge ( 2.25 tonnes/ha, twice annually) and the C plots with conventional inorganic fertilizer containing the same amount of nitrogen. The sludge was applied, each year, before the seasonal onset of pasture growth (March; late gestation) and before the final month of significant growth (September; approximately two months before mating). The plots were managed so that the pasture height was maintained at an optimal height, as far as possible; this was achieved by adding and removing non-experimental animals from the plots, as required, to manage herbage mass and to ensure that the nutritional state of the animals of the respective treatments remained similar at all times.

In total, 24 male $(12 \mathrm{~T} ; 12 \mathrm{C})$ and 24 female $(12 \mathrm{~T} ; 12 \mathrm{C})$ offspring from the respective treatments were used in the study. $\mathrm{T}$ animals were exposed to the pollutants in sewage sludge from conception until weaning at approximately 4 months of age via their dams, in utero and through milk, and through exposure to sludge-treated pasture from when they began to consume herbage. After weaning, owing to the need to avoid uncontrolled matings and to other requirements of the experimental programme, male lambs were kept on control pastures until slaughter while female lambs remained on the respective $\mathrm{T}$ or $\mathrm{C}$ pastures. All experimental animals were slaughtered at 18 months of age, femurs removed and blood samples were collected and plasma separated and stored at $-20^{\circ} \mathrm{C}$.

\subsection{Sludge collection and analysis}

Sub-samples of the sludge and inorganic fertiliser applied to the $\mathrm{T}$ and $\mathrm{C}$ pastures, respectively, were collected and analysed for selected EDCs. The concentrations of selected PCB and PBDE congeners (AccuStandard, USA) and 16 USEPA priority PAHs (Greyhound Chromatography, UK) were determined as follows:

For PCBs and PBDEs, sludge samples (approximately $1 \mathrm{~g}$ dry weight) were spiked with $0.01 \mathrm{mg}$ internal standards of ${ }^{13} \mathrm{C}$ PCB-138 and ${ }^{13} \mathrm{C}$ PBDE-99 (Greyhound Chromatography, UK) and $8 \mathrm{ml}$ ethanoic potassium hydroxide $(1 \mathrm{M})$ was added. It was heated at approximately $90^{\circ} \mathrm{C}$ for $8 \mathrm{~h}$. The samples were allowed to cool and $2 \mathrm{ml}$ of Milli-Q water added. Samples were extracted into $3 \times 10 \mathrm{ml}$ iso-hexane and the extracts were then concentrated to $0.5 \mathrm{ml}$ under a gentle stream of nitrogen. Sample clean-up was achieved using absorption chromatography to remove lipids, primarily, using in-house prepared columns (25 cm length, $15 \mathrm{~mm}$ i.d, fitted with PTFE taps). The extracts were loaded on to a $5 \mathrm{~g}$ silica (Merck, UK), $10 \mathrm{~g}$ of acid modified (2:1, silica:sulphuric acid) and $1 \mathrm{~g}$ anhydrous $\mathrm{Na}_{2} \mathrm{SO}_{4}$ column, conditioned with $40 \mathrm{ml}$ iso-hexane (Rathburn Chemicals, UK). Sample was loaded and eluted by $20 \mathrm{ml}$ discarded iso-hexane, and then eluted by $80 \mathrm{ml}$ of iso-hexane which was 
collected. For PAHs, $1 \mathrm{~g}$ of dry samples were spiked with 7 deuterated internal standards (d8-naphthalene, d10-acenaphthene, d10-fluorene, d10-phenanthrene, d10-anthracene, d10-pyrene and d12-chrysene; $0.3 \mu \mathrm{g}$; Greyhound Chromatography, UK) and then were saponified and extracted using the method described for PCBs and PBDEs. For clean-up of PAH extracts, a column comprising $10 \mathrm{~g}$ activated silica gel and $1 \mathrm{~g}$ anhydrous $\mathrm{Na}_{2} \mathrm{SO}_{4}$ was used. It was conditioned with $40 \mathrm{ml}$ iso-hexane and, for collection, was eluted with $50 \mathrm{ml}$ of 1:1 DCM:iso-hexane. The fractions collected were concentrated to $0.1 \mathrm{ml}$ by rotary-evaporation and under a gentle stream of nitrogen and were then ready for analysis using gas chromatography linked to mass spectrometry (GC-MS).

Thermo Electron Trace MS (Hemel Hempstead, UK) linked to a Trace 2000 GC with an AS2000 autosampler, was used for PCBs, PBDEs and PAHs analysis with selected ion mode (SIM; Table 1). The capillary column was ZB-5MS (30 $\mathrm{m} \times 0.25 \mathrm{~mm}$ i. d. $\times 0.25 \mu \mathrm{m}$ film thickness, Phenomenex, UK). The tempera-

Table 1 - Mass to charge ratio of ions monitored for PCBs, PBDEs and PAHs

\begin{tabular}{|c|c|}
\hline & $\mathrm{m} / \mathrm{z}^{2}$ \\
\hline PCB-28 & 256 \\
\hline PCB-52 & 220 \\
\hline PCB-101 & 326 \\
\hline РCB-118 & 326 \\
\hline PCB-138 & 360 \\
\hline РCB-153 & 360 \\
\hline PCB-180 & 394 \\
\hline${ }^{13} \mathrm{C} 138 ?$ & 372 \\
\hline PBDE-28 & 406 \\
\hline PBDE-47 & 326 \\
\hline PBDE-99 & 566 \\
\hline PBDE-100 & 566 \\
\hline PBDE-153 & 644 \\
\hline PBDE-154 & 644 \\
\hline PBDE-183 & 722 \\
\hline 13C 99 & 416 \\
\hline Naphthalene & 128 \\
\hline Acenaphthalene & 152 \\
\hline Acenaphthene & 153 \\
\hline Fluorene & 166 \\
\hline Phenanthrene & 178 \\
\hline Anthracene & 178 \\
\hline Fluoranthene & 202 \\
\hline Pyrene & 202 \\
\hline Benzo[a]anthracene & 228 \\
\hline Chrysene & 228 \\
\hline Benzo[b]fluoranthene & 252 \\
\hline Benzo[k]fluoranthene & 252 \\
\hline Benzo[a]pyrene & 252 \\
\hline Indeno[1,2,3-cd]pyrene & 276 \\
\hline Dibenzo[a,h]anthracene & 278 \\
\hline Benzo[ghl]perylene & 276 \\
\hline d-8 Naphthalene & 136 \\
\hline d-10 Acenaphthene & 164 \\
\hline$d$-10 Fluorene & 176 \\
\hline d-10 Phenanthrene & 188 \\
\hline d-10 Anthracene & 188 \\
\hline d-10 Pyrene & 212 \\
\hline d-12 Chrysene & 240 \\
\hline
\end{tabular}

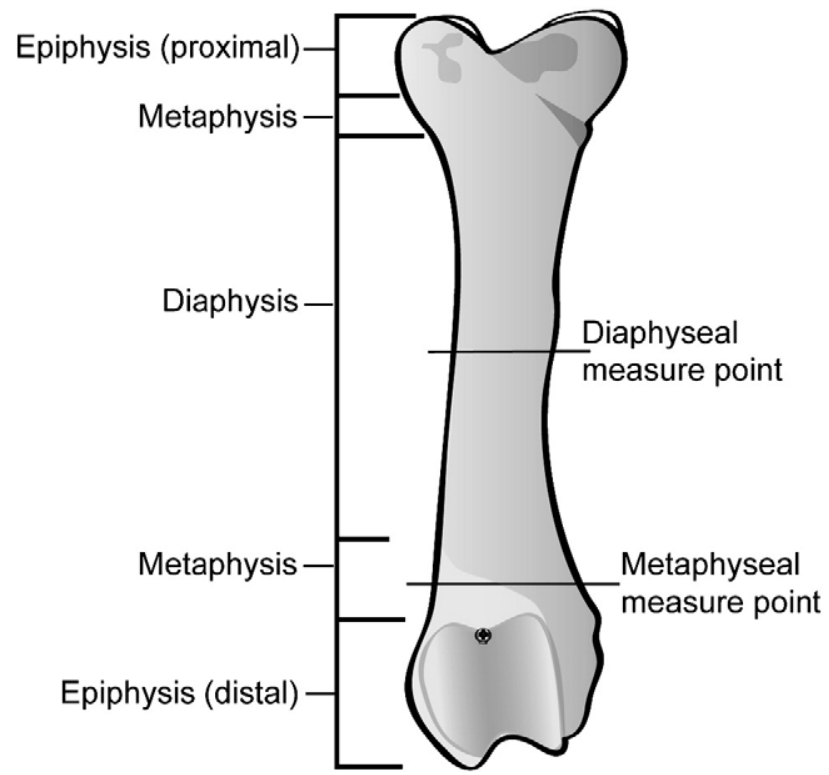

Fig. 1-Schematic overview of the inserted screw and measure points as used for PQCT analysis.

ture program for PCB started at $120{ }^{\circ} \mathrm{C}$ for 1 minute; the temperature was then ramped at $4{ }^{\circ} \mathrm{C} / \mathrm{min}$ to $280^{\circ} \mathrm{C}$ and held for $1 \mathrm{~min}$ and then ramped to $320^{\circ} \mathrm{C}$ at $30^{\circ} \mathrm{C} / \mathrm{min}$ and held for $5 \mathrm{~min}$. The operating temperature for PBDE was programmed from $70^{\circ} \mathrm{C}(1 \mathrm{~min})$ to $170{ }^{\circ} \mathrm{C}$ at $30^{\circ} \mathrm{C} / \mathrm{min}$ and then ramped to $300^{\circ} \mathrm{C}$ at $8^{\circ} \mathrm{C} / \mathrm{min}$ and held for $5 \mathrm{~min}$. The temperature for PAH was programmed from $70{ }^{\circ} \mathrm{C}(3 \mathrm{~min})$ to $250{ }^{\circ} \mathrm{C}$ at $5^{\circ} \mathrm{C} / \mathrm{min}$ and held for $1 \mathrm{~min}$, then ramped to $300^{\circ} \mathrm{C}$ at $6^{\circ} \mathrm{C} / \mathrm{min}$ and held for 6 min and finally ramped to $325^{\circ} \mathrm{C}$ at $10^{\circ} \mathrm{C} / \mathrm{min}$ and held for $5 \mathrm{~min}$. The carrier gas was helium and samples were injected in splitless mode with a surge. The injector and mass spectrometer were held at $250{ }^{\circ} \mathrm{C}$ and $200{ }^{\circ} \mathrm{C}$ respectively. The electron impact energy was set $70 \mathrm{eV}$ for mass spectrometer.

Before sample analysis, relevant standards were analyzed to check column performance, peak height and resolution, and the limits of detection (LoD). LoD was calculated to be $0.02 \mu \mathrm{g} / \mathrm{kg}$ for all PCBs, $0.02 \mu \mathrm{g} / \mathrm{kg}$ for PBDE 28, 47, 99 and 100 and $0.50 \mu \mathrm{g} / \mathrm{kg}$ for PBDE 153, 154 and 183. The LoD was $1 \mu \mathrm{g} / \mathrm{kg}$ for all PAHs except phenanthrene, fluoranthene, benzo[k] fluoranthene, indenol[1,2,3-cd]pyrene and dibenzo[a,h] anthracene for which they were $5 \mu \mathrm{g} / \mathrm{kg}$ and pyrene for which it was $15 \mu \mathrm{g} / \mathrm{kg}$. With each set of samples analysed, a standard mixture, quality control samples, and a procedural blank were run in sequence to check for contamination, recovery, peak identification and quantification. Compounds were identified mainly by selected ion and their retention times. All results for sludge samples were reported on a dryweight basis.

\subsection{Bone preparations}

Femur bones were cleaned and stored at $-20{ }^{\circ} \mathrm{C}$. Before analysis, using peripheral Quantitative Computed Tomography (pQCT), bones were moved to a refrigerator $\left(+8{ }^{\circ} \mathrm{C}\right)$ and thawed for approximately $24 \mathrm{~h}$. The preparation of the bones 
for the PQCT analysis has been described in previous studies (Hermsen et al., 2008; Lundberg et al., 2006). In brief, femur lengths were measured to the nearest $0.1 \mathrm{~mm}$, using a slide calliper. A screw $(2.5 \times 12 \mathrm{~mm}$; DynaPlus, zinc plated) inserted dorsal to the trochlea ossis femori was used as a reference point for the pQCT analyses (Fig. 1). The bones were covered with gauze bandage (Molleplast, elastic, Lohmann \& Rauscher AG, Switzerland), moistened with Ringers solution ( $\mathrm{pH} 7.4$; Tris (0.3 g/l), $\left.\mathrm{NaCl}(9 \mathrm{~g} / \mathrm{l}), \mathrm{CaCl}_{2} \cdot \mathrm{H}_{2} \mathrm{O}(0.24 \mathrm{~g} / \mathrm{l}), \mathrm{KCl}(0.4 \mathrm{~g} / \mathrm{l})\right)$ and then wrapped in polyethylene plastic foil to prevent drying.

\section{4. $\quad p Q C T$ measurements}

pQCT (Stratec XCT 960 A with software version 5.21; Norland Stratec Medizintechnik, Pforzheim) was used to estimate dimensions and densiometric variables of the femurs. The pQCT instrument was calibrated once each week with a hydroxyapatite phantom of known density (Gasser, 2003). The femurs were placed horizontally in the pQCT instrument with the distal end at the front and the anterior side facing upwards. The position of the bone was examined with the scout view of the pQCT. The femurs were analysed using voxelsize $590 \mu \mathrm{m}$. The settings used were: peel mode 2, contour mode 1 , threshold $270 \mathrm{mg} / \mathrm{cm}^{3}$, inner threshold $500 \mathrm{mg} / \mathrm{cm}^{3}$ and outer threshold $690 \mathrm{mg} / \mathrm{cm}^{3}$.

\subsubsection{Metaphyseal measurements}

The metaphysis (Fig. 2) of the bone was analysed by examining a $3 \mathrm{~mm}$ thick slice at $3.6 \%$ of the total bone length from the reference point located at the trochlea ossis femori in the distal part of the femur; at this site there is a continuous layer of cortical bone surrounding the inner trabecular bone. The variables evaluated were total bone mineral content (BMC, $\mathrm{mg} / \mathrm{mm}$ ), total bone mineral density $\left(B M D, \mathrm{mg} / \mathrm{cm}^{3}\right)$, trabecular (trab) BMC $(\mathrm{mg} / \mathrm{mm})$, trab BMD $\left(\mathrm{mg} / \mathrm{cm}^{3}\right)$, total cross sectional area $\left(\mathrm{CSA}, \mathrm{mm}^{2}\right)$, trab CSA $\left(\mathrm{mm}^{2}\right)$, and periosteal circumference (PERIC, $\mathrm{mm}$ ).

\subsubsection{Diaphyseal measurements}

The diaphysis of the bone was analysed by examining a $1 \mathrm{~mm}$ thick slice at $50 \%$ of the total bone length; this site consists, mainly, of cortical (cort) bone. The variables evaluated were total BMC $(\mathrm{mg} / \mathrm{mm})$, total BMD $\left(\mathrm{mg} / \mathrm{cm}^{3}\right)$, total CSA $\left(\mathrm{mm}^{2}\right)$, cort BMC $(\mathrm{mg} / \mathrm{mm})$, cort BMD $\left(\mathrm{mg} / \mathrm{cm}^{3}\right)$, cort CSA $\left(\mathrm{mm}^{2}\right)$, cort thickness (cort THKC, mm), PERIC (mm), endosteal circumference (ENDOC, $\mathrm{mm}$ ), polar moment of inertia $\left(\mathrm{mm}^{4}\right)$ and marrow cavity $\left(\mathrm{mm}^{2}\right)$.

\subsubsection{Reproducibility}

To evaluate the reproducibility of the pQCT measurements, the coefficients of variation (CV \%) for the different variables were calculated from 10 repeated measurements with a single sample which was repositioned before each measurement. The CV for the ten different pQCT measurements at the metaphyseal measure point were: 0.4\% (total BMC), 0.3\% (total BMD), $1.5 \%$ (trab BMC), 1.5\% (trab BMD), 0.6\% (total CSA), $1.1 \%$ (trab CSA) and $0.3 \%$ (PERIC). The CV for the ten different pQCT measurements at the diaphyseal measure point were: $0.2 \%$ (total BMC), 0.2\% (total BMD), 0.2\% (total CSA), 0.2\% (cort BMC), $0.2 \%$ (cort BMD), $0.3 \%$ (cort CSA), $0.5 \%$ (cortTHKC), $0.1 \%$ (PERIC), $0.3 \%$ (ENDOC), $0.3 \%$ (Polar moment of intertia) and $0.2 \%$ (marrow cavity).

\subsubsection{Biomechanical testing}

The three-point bending test (mid-part bent until fracture) measurements were conducted at the mid-diaphyseal part of the femur. A servo-hydraulic material testing machine (MTS 858 Mini Bionix with Teststar II data acquisition with software Testware SX version 3.1B, MTS corp, Minneapolis, MN, USA) was used for the tests. A load cell with maximum capacity of $10000 \mathrm{~N}$ was used. The span length was $100 \mathrm{~mm}$ and the loading speed $1 \mathrm{~mm} / \mathrm{s}$. Following thawing, the load was applied on the point that was used in the diaphyseal pQCT measurement (50\% of the total bone length). The load $(N)$ applied and the displacement $(\mathrm{mm})$ of the crosshead was recorded at a sampling rate of $50 \mathrm{~Hz}$. Based on the load and displacement data the stiffness $(\mathrm{N} / \mathrm{mm})$ and energy until failure $(\mathrm{N} \times \mathrm{mm})$ were calculated. The maximal stiffness was defined, based on the steepest part of the load-displacement curve. The load displacement values collected with $50 \mathrm{~Hz}$ during the testing were used to calculate energy to failure by applying a formula that calculated the cumulative area under
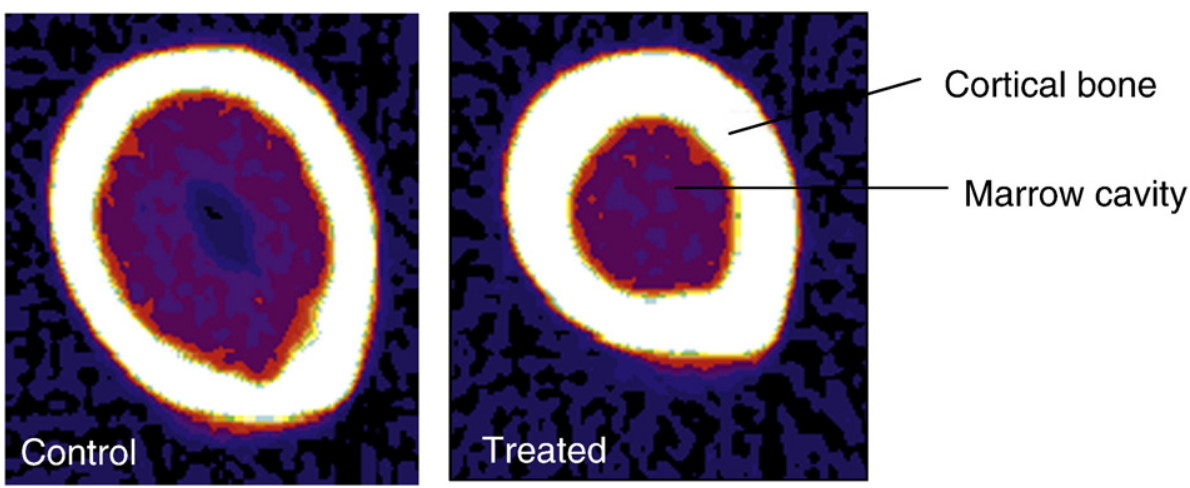

Fig. 2-Representative images from the pQCT scan at the $50 \%$ measure point from male sheep. The white outer part is cortical bone and the inner darker part is the marrow cavity. To the left control and to the right treated (T). Note the small area of the marrow cavity, the shorter endosteal circumference and periosteal circumference and the increased cortical thickness in the $T$ specimen. 
the load displacement curve. By using such a formula a fairly precise assessment of the energy to failure could be obtained irrespective of the degree of non-linearity of the load displacement curve. The same equipment and methodology was used in several studies (Fox et al., 2008; Lind et al., 2000a; Lundberg et al., 2006) with slight adjustments to accommodate the specific bones being tested.

\subsubsection{Analysis of bone biomarkers}

The analyses of the levels of the biochemical marker BAP (bone specific alkaline phosphatase, Ostase BAP Immunoenzymetric Assay) for bone formation (osteoblast activity) was performed according to the manufacturer's instructions (Nordic Bioscience Diagnostics A/S, Herlev, Denmark). Briefly, $50 \mu \mathrm{L}$ of standards, controls and plasma specimen (duplicates) were incubated with $100 \mu \mathrm{L}$ of conjugate (primary antibody) for $1 \mathrm{~h}$ at $18-25^{\circ} \mathrm{C}$. After washing, the specimens were incubated for $15 \mathrm{~min}$ at $18-25{ }^{\circ} \mathrm{C}$. After stopping the reaction, the absorbance was measured at 450 and $595 \mathrm{~nm}$ (Molecular Devices Kinetic Reader). The results were analysed using point-to-point curve fit (SoftMax Pro). A standard curve was retrieved and used for the determination of the concentration ( $\mu \mathrm{g} \mathrm{BAP} / \mathrm{L}$ ) in the plasma samples.

The levels of the biochemical marker CTX (carboxyterminal telopeptide of type 1 collagen) for bone resorption (osteclast activity) were analysed according to the manufacturer's instructions (Serum Crosslaps ELISA, Nordic Bioscience Diagnostics A/S, Herlev, Denmark). This is an in vitro enzyme immunological test for the quantification of degradation products of CTX. Briefly, $50 \mu \mathrm{L}$ (duplicates) of standards, controls and specimens were incubated with $150 \mu \mathrm{L}$ of antibody solution were incubated at $18-22{ }^{\circ} \mathrm{C}$ on a 96 -well plate for $2 \mathrm{~h}$. After washing and adding $100 \mu \mathrm{L}$ of substrate solution, the plate was incubated for $15 \mathrm{~min}$ at $18-22^{\circ} \mathrm{C}$ in the dark. After quenching the reaction, the absorbance was measured at 450 and $595 \mathrm{~nm}$ (Tecan Magellan Plate Reader). The results were analysed using quadratic curve fit (Assay Zap software 3.1, Biosoft, Cambridge, UK) with absorbance values from the standards and the CrossLaps concentrations. Plasma concentrations $(\mathrm{ng} / \mathrm{mL})$ were determined by the equation of the curve.

Concentrations of vitamin D were analysed according to the manufacturer's instructions (25-Hydroxy Vitamin D (25-OH D) EIA, Immunodiagnostic Systems Ltd). This is an enzymatic immunoassay for determination of 25-OH D and other hydroxylated metabolites. Briefly, $200 \mu \mathrm{L}$ of calibrators and specimen were incubated at $18-25^{\circ} \mathrm{C}$ on a 96 -well plate for $2 \mathrm{~h}$. After washing, $200 \mu \mathrm{L}$ enzyme conjugate was added and the plate was incubated at $18-25^{\circ} \mathrm{C}$ for $30 \mathrm{~min}$. After a second washing, $200 \mu \mathrm{L}$ TMB (tetramethylbenzedine) was added and the plate was incubated at $18-25^{\circ} \mathrm{C}$ for $30 \mathrm{~min}$ to quench the reaction. After quenching the reaction, the absorbance was measured at 450 and $595 \mathrm{~nm}$ (Tecan Magellan Plate Reader). A standard curve with percent binding $(\mathrm{B} / \mathrm{B} \%=$ (mean absorbance/(mean absorbance for 0 calibrator) $\times 100$ ) of each calibrator was calculated retrieved using four parameter logistic curve fit (4PL, Assay Zap software 3.1, Biosoft, Cambridge, UK). The standard curve was used for the determination of the concentration of $25-\mathrm{OH} \mathrm{D}(\mathrm{nmol} / \mathrm{L})$ in the samples.

\subsection{Statistical analysis}

The results were evaluated using t-test (Graph Pad Prism, version 4.03) and, thereafter, analysis of covariance (ANCOVA, StatView, version 5.0; SAS Institute Inc., Cary, NC, USA) was applied to adjust for differences in bodyweight, since bodyweight may influence the different outcome parameters. $\mathrm{P}<0.05$ was considered to be statistically significant.

\section{Results}

Concentrations of selected PCBs, PBDEs and PAHs in sludge and inorganic fertilizer are given in Table 2.

\subsection{Bone measurements}

\subsubsection{Rams}

Fig. 2 and Table 3 present the results obtained from the pQCT measurements and the biomechanical testing of ram femurs. Sewage sludge exposed animals (treated, T) exhibited significantly a greater total BMD $(+10.5 \%, p<0.01)$ and lower total CSA $(-11.5 \%, p<0.001)$, trab CSA $(-17.1 \%, p<0.01)$, and PERIC $(-5.7 \%$, $p<0.001)$ at the metaphysis of the femurs, compared to $C$ animals.

In addition, at the diaphysis, sewage sludge exposure was associated with a significantly increased total BMD (+13.8\%,

Table 2 - Concentrations ( $\mu \mathrm{g} / \mathrm{kg}$ ) of selected PCB. PBDE and $\mathrm{PAH}$ in single pooled samples of sludge and inorganic fertilizer applied to $\mathbf{T}$ and $\mathbf{C}$ pastures

\begin{tabular}{llc} 
Pollutant & Sludge & Inorganic fertilizer \\
\hline PCB-28 & 32.57 & N/D \\
PCB-52 & 10.11 & N/D \\
PCB-101 & 2.08 & 0.04 \\
PCB-118 & 9.34 & 0.25 \\
PCB-138 & 5.58 & N/D \\
PCB-153 & 10.75 & 0.03 \\
PCB-180 & 4.55 & N/D \\
PBDE-28 & 6.71 & N/D \\
PBDE-47 & 162.1 & N/D \\
PBDE-99 & 202.2 & 0.94 \\
PBDE-100 & 9.46 & N/D \\
PBDE-153 & 20.03 & N/D \\
PBDE-154 & 151.0 & 8.17 \\
PBDE-183 & 7.45 & N/D \\
Naphthalene & 21.0 & N/D \\
Acenaphthalene & 33.9 & N/D \\
Acenaphthene & 109 & N/D \\
Fluorene & 210 & N/D \\
Phenanthrene & 1773 & N/D \\
Anthracene & 1155 & N/D \\
Fluoranthene & 1493 & N/D \\
Pyrene & 1493 & N/D \\
Benzo[a]anthracene & 1071 & N/D \\
Chrysene & 601 & N/D \\
Benzo[b]fluoranthene & 2169 & N/D \\
Benzo[k]fluoranthene & 375 & N/D \\
Benzo[a]pyrene & 425 & N/D \\
Indeno[1,2,3-cd]pyrene & 2171 & N/D \\
Dibenzo[a,h]anthracene & 786 & N/D \\
Benzo[ghl]perylene & 359 & N/D \\
\hline N/D = not detectable. & & \\
& &
\end{tabular}


Table 3 - Results of pQCT analysis and three-point bending test (biomechanical testing) of the femurs of the rams

RAM

\begin{tabular}{|c|c|c|c|c|c|}
\hline & & \multirow{2}{*}{$\begin{array}{l}\text { Control } \\
(n=12)\end{array}$} & \multirow{2}{*}{$\begin{array}{c}\text { Treated } \\
(n=12)\end{array}$} & \multicolumn{2}{|c|}{$p$-value } \\
\hline & & & & t-test & ANCOVA \\
\hline \multirow[t]{21}{*}{ pQCT } & Metaphysis, 3.6\% & & & & \\
\hline & Weight (kg) & $77.9 \pm 1.0$ & $80.3 \pm 1.8$ & ns & - \\
\hline & Total BMC $(\mathrm{mg} / \mathrm{mm})$ & $432.9 \pm 14.0$ & $427.6 \pm 9.4$ & ns & ns \\
\hline & Total BMD $\left(\mathrm{mg} / \mathrm{cm}^{3}\right)$ & $459.7 \pm 15.7$ & $508.0 \pm 11.1$ & $<0.0001$ & $<0.01$ \\
\hline & Trab BMC $(\mathrm{mg} / \mathrm{mm})$ & $152.2 \pm 9.8$ & $140.0 \pm 8.1$ & ns & ns \\
\hline & Trab BMD $\left(\mathrm{mg} / \mathrm{cm}^{3}\right)$ & $264.6 \pm 18.4$ & $281.6 \pm 10.1$ & ns & ns \\
\hline & Total CSA $\left(\mathrm{mm}^{2}\right)$ & $945.2 \pm 21.1$ & $847.8 \pm 29.6$ & $<0.0001$ & $<0.001$ \\
\hline & Trab CSA $\left(\mathrm{mm}^{2}\right)$ & $583.8 \pm 24.7$ & $498.6 \pm 26.5$ & $<0.0001$ & $<0.01$ \\
\hline & PERIC (mm) & $108.9 \pm 1.2$ & $103.0 \pm 1.8$ & $<0.0001$ & $<0.001$ \\
\hline & Diaphysis, 50\% & & & & \\
\hline & Total BMC (mg/mm) & $380.4 \pm 10.0$ & $384.6 \pm 8.5$ & ns & ns \\
\hline & Total BMD $\left(\mathrm{mg} / \mathrm{cm}^{3}\right)$ & $643.6 \pm 16.9$ & $732.3 \pm 15.9$ & $<0.001$ & $<0.0001$ \\
\hline & Total CSA $\left(\mathrm{mm}^{2}\right)$ & $592.9 \pm 14.2$ & $528.8 \pm 19.1$ & $<0.01$ & $<0.0001$ \\
\hline & Cort BMC $(\mathrm{mg} / \mathrm{mm})$ & $338.7 \pm 10.0$ & $346.3 \pm 7.8$ & ns & ns \\
\hline & Cort BMD $\left(\mathrm{mg} / \mathrm{cm}^{3}\right)$ & $1315.7 \pm 3.9$ & $1321.6 \pm 4.0$ & ns & ns \\
\hline & Cort CSA $\left(\mathrm{mm}^{2}\right)$ & $257.4 \pm 7.4$ & $262.1 \pm 6.2$ & ns & ns \\
\hline & CortTHKC (mm) & $3.4 \pm 0.1$ & $3.8 \pm 0.1$ & $<0.01$ & $<0.05$ \\
\hline & PERIC (mm) & $86.2 \pm 1.0$ & $81.4 \pm 1.4$ & $<0.05$ & $<0.0001$ \\
\hline & ENDOC (mm) & $64.8 \pm 1.3$ & $57.7 \pm 1.6$ & $<0.01$ & $<0.0001$ \\
\hline & Polar moment $\left(\mathrm{mm}^{4}\right)$ & $39493.3 \pm 1728.7$ & $34550.9 \pm 2170.5$ & ns & $<0.01$ \\
\hline & Marrow cavity $\left(\mathrm{mm}^{2}\right)$ & $335.6 \pm 12.9$ & $266.7 \pm 14.7$ & $<0.01$ & $<0.0001$ \\
\hline \multirow[t]{5}{*}{ Biomechanics } & Diaphysis, 50\% & & & & \\
\hline & Displacement $(\mathrm{mm})$ & $4.2 \pm 0.4$ & $4.4 \pm 0.2$ & Ns & ns \\
\hline & Load $(N)$ & $5440.7 \pm 320.3$ & $6396.7 \pm 153.6$ & $<0.05$ & ns \\
\hline & Energy $(\mathrm{N} \times \mathrm{mm})$ & $15823.9 \pm 17744.6$ & $16663.1 \pm 1316.6$ & ns & ns \\
\hline & Stiffness $(\mathrm{N} / \mathrm{mm})$ & $2570.4 \pm 84.9$ & $2734.4 \pm 124.2$ & ns & $<0.01$ \\
\hline
\end{tabular}

$p<0.0001)$ and cort THKC $(+11.8 \% p<0.05)$ but significantly decreased total CSA $(-12.1 \%, p<0.0001)$, PERIC $(-5.9 \%$, $p<0.0001)$, ENDOC $(-12.3 \%, p<0.0001)$ and marrow cavity $(-25.8 \%, p<0.0001)$ relative to $\mathrm{C}$ animals (Fig. 2). The polar moment of inertia, a theoretical prediction of the bone's ability to resist torsion was also reduced in the treated animals $(-9.4 \%, p<0.0001)$. Sewage sludge exposure was associated with significantly increased femoral stiffness $(+6.4 \%, p<0.01)$ relative to $C$ rams.

\subsubsection{Ewes}

The results of the pQCT and the three-point bending test on the ewe femurs are given in Table 4. In ewes although pQCT analysis of neither the metaphyseal nor the mid-diaphyseal part of the female femur bones showed significant differences with treatment, the biomechanical method revealed a reduction in load at failure $(-17.3 \%, p<0.01)$ and stiffness $(-10.7 \%$, $p<0.05)$ amongst $\mathrm{T}$ ewes.

\subsection{Analysis of bone biomarkers}

There were no significant differences between $\mathrm{T}$ and $\mathrm{C}$ animals in any of the biomarker measurements in either rams (Table 5) or ewes (Table 6).

\section{Discussion}

The present study is the first reported study exploring the effects on bone tissue of breeding sheep on pastures fertilized with sewage sludge. The analyses of the sludge and inorganic fertiliser indicate that the sludge contained significant quantities of organic pollutants which were virtually absent in the inorganic fertiliser. While the precise pattern of animal exposure cannot be deduced from these data, it is clear that all $\mathrm{T}$ animals were exposed to above-background levels of pollutants through the sludge, from conception until weaning, via their dams, in utero and through milk, or through consumption of grass. Accurate assessment of pollutant burden in the target tissue is logistically extremely difficult, firstly because several thousand chemicals may be involved, each of which has different characteristics and is present at low concentrations, often close to the limits of detection. Furthermore, exposure depends on the rate of environmental degradation and availability of these chemicals, their concentration in ingested feed, rates of uptake, excretion and metabolism by the animal and the efficiency with which it is assimilated in the tissue (Rhind, 2008). Finally, each of these processes is likely to change with both time and stage of development of the animal (Rhind, 2008). Risks of tissue 
Table 4-Results of pQCT analysis and three-point bending test (biomechanical testing) of the femurs of the ewes EWE

\begin{tabular}{|c|c|c|c|c|c|}
\hline & & \multirow{2}{*}{$\begin{array}{l}\text { Control } \\
(n=12)\end{array}$} & \multirow{2}{*}{$\begin{array}{l}\text { Treated } \\
(n=12)\end{array}$} & \multicolumn{2}{|c|}{$p$-value } \\
\hline & & & & t-test & ANCOVA \\
\hline \multirow[t]{21}{*}{ pQCT } & Metaphysis, 3.6\% & & & & \\
\hline & Weight (kg) & $63.6 \pm 1.0$ & $61.2 \pm 1.2$ & ns & - \\
\hline & Total BMC (mg/mm) & $363.7 \pm 7.2$ & $346.0 \pm 9.6$ & $<0.05$ & ns \\
\hline & Total BMD $\left(\mathrm{mg} / \mathrm{cm}^{3}\right)$ & $510.7 \pm 15.5$ & $473.7 \pm 13.6$ & $<0.01$ & ns \\
\hline & Trab BMC (mg/mm) & $201.3 \pm 8.7$ & $234.6 \pm 12.2$ & $<0.001$ & ns \\
\hline & Trab BMD $\left(\mathrm{mg} / \mathrm{cm}^{3}\right)$ & $719.3 \pm 25.2$ & $736.5 \pm 27.3$ & ns & ns \\
\hline & Total CSA $\left(\mathrm{mm}^{2}\right)$ & $371.9 \pm 22.8$ & $442.7 \pm 27.2$ & $<0.001$ & ns \\
\hline & $\operatorname{Trab} \operatorname{CSA}\left(\mathrm{mm}^{2}\right)$ & $94.9 \pm 1.6$ & $96.0 \pm 1.8$ & ns & ns \\
\hline & PERIC (mm) & $63.6 \pm 1.0$ & $61.2 \pm 1.2$ & ns & - \\
\hline & Diaphysis, 50\% & & & & \\
\hline & Total BMC (mg/mm) & $305.2 \pm 6.7$ & $285.5 \pm 6.8$ & ns & ns \\
\hline & Total BMD $\left(\mathrm{mg} / \mathrm{cm}^{3}\right)$ & $671.1 \pm 14.7$ & $659.0 \pm 17.4$ & ns & ns \\
\hline & Total CSA $\left(\mathrm{mm}^{2}\right)$ & $456.5 \pm 11.7$ & $434.7 \pm 9.1$ & ns & ns \\
\hline & Cort BMC $(\mathrm{mg} / \mathrm{mm})$ & $271.5 \pm 6.7$ & $254.0 \pm 6.8$ & ns & ns \\
\hline & Cort BMD $\left(\mathrm{mg} / \mathrm{cm}^{3}\right)$ & $1322.3 \pm 8.8$ & $1316.2 \pm 5.9$ & ns & ns \\
\hline & Cort CSA $\left(\mathrm{mm}^{2}\right)$ & $205.2 \pm 4.6$ & $192.9 \pm 4.8$ & ns & ns \\
\hline & CortTHKC (mm) & $3.1 \pm 0.1$ & $3.0 \pm 0.1$ & ns & ns \\
\hline & PERIC (mm) & $75.7 \pm 1.0$ & $73.9 \pm 0.8$ & ns & ns \\
\hline & ENDOC $(\mathrm{mm})$ & $56.1 \pm 1.1$ & $55.0 \pm 1.0$ & ns & ns \\
\hline & Polar moment $\left(\mathrm{mm}^{4}\right)$ & $23979.2 \pm 1056.0$ & $21456.6 \pm 813.7$ & ns & ns \\
\hline & Marrow cavity $\left(\mathrm{mm}^{2}\right)$ & $251.3 \pm 9.7$ & $241.8 \pm 8.9$ & ns & ns \\
\hline \multirow[t]{5}{*}{ Biomechanics } & Diaphysis, 50\% & & & & \\
\hline & Displacement (mm) & $3.5 \pm 0.2$ & $4.0 \pm 0.3$ & ns & ns \\
\hline & Load $(N)$ & $4851.4 \pm 139.3$ & $4134.5 \pm 194.0$ & $<0.05$ & $<0.01$ \\
\hline & Energy $(\mathrm{N} \times \mathrm{mm})$ & $10236.9 \pm 583.2$ & $11884.9 \pm 970.3$ & ns & ns \\
\hline & Stiffness $(\mathrm{N} / \mathrm{mm})$ & $2183.1 \pm 125.4$ & $1971.8 \pm 110.7$ & ns & $<0.05$ \\
\hline
\end{tabular}

accumulation of several pollutant groups have been assessed for ruminants grazing pastures treated with sludge (Fries and Marrow, 1977; Smith, 1996) and concentrations of selected organic pollutants and heavy metals in sheep maintained on the same pastures as those in the present study have been reported (Rhind et al., 2007; Rhind et al., 2005a; Rhind et al., $2005 \mathrm{~b}$ ). Both predicted and actual concentrations of various pollutants in tissue, following exposure to treated pastures,

Table 5 - Mean ( \pm SE) plasma concentrations of bone-specific alkaline phosphatase (BAP), carboxyterminal telopeptide of type 1 collagen (CTX) and 25-OH D=25-hydroxy vitamin D (25-OHD) in rams

RAM

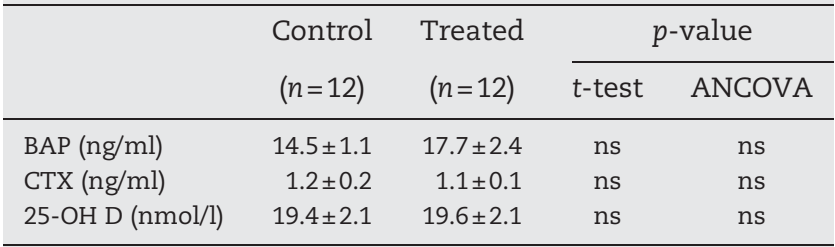

Differences between groups were evaluated by ANCOVA with adjustments for body weight since body weight may influence the different outcome parameters. ns = non-significant. including heavy metals and organic pollutants were low and not consistently increased, relative to control pastures. However, these measurements may not provide an index of exposure at the many stages of development before slaughter at which bone development may be affected. Increases in exposure as a result of grazing sludge treated pasture may be transient and variable, depending on climatic and pasture conditions.

Table 6 - Mean ( \pm SE) plasma concentrations of

bone-specific alkaline phosphatase (BAP),

carboxyterminal telopeptide of type 1 collagen (CTX) and

25-OH D =25-hydroxy vitamin D (25-OHD) in ewes

EWE

\begin{tabular}{|c|c|c|c|c|}
\hline & \multirow{2}{*}{$\begin{array}{l}\text { Control } \\
(n=12)\end{array}$} & \multirow{2}{*}{$\begin{array}{l}\text { Treated } \\
(n=12)\end{array}$} & \multicolumn{2}{|c|}{$p$-value } \\
\hline & & & t-test & ANCOVA \\
\hline $\mathrm{BAP}(\mathrm{ng} / \mathrm{ml})$ & $15.1 \pm 1.4$ & $18.1 \pm 1.9$ & ns & ns \\
\hline CTX (ng/ml) & $0.6 \pm 0.1$ & $0.6 \pm 0.1$ & ns & ns \\
\hline 25-OH D (nmol/l) & $24.3 \pm 2.8$ & $25.0 \pm 3.4$ & ns & ns \\
\hline
\end{tabular}

Differences between groups were evaluated by ANCOVA with adjustments for body weight since body weight may influence the different outcome parameters. ns = non-significant. 
Notwithstanding the difficulties of defining exposure dose, the results of the studies indicate that exposure to pollutants via sewage sludge can perturb bone tissue homeostasis in sheep. This effect was most pronounced in male offspring (rams). The exposed rams exhibited marked effects especially in the diaphysis of the femur, including reduced CSA and marrow cavity but increased cortical thickness (Fig. 2). In contrast, the female offspring (ewes) exhibited no changes in PQCT variables but the three-point bending test, however, showed that the exposed ewes in the present study had more fragile bone (lower load at failure and reduced stiffness) than the $\mathrm{C}$ ewes. Similar reductions in bone strength have been reported previously in studies of rats exposed to dioxin and dioxin like PCBs (Jamsa et al., 2001; Lind et al., 2000b; Miettinen et al., 2005) and a PCB mixture (Andrews, 1989).

The differences in responses between rams and ewes in the present study could be a reflection of the difference in the duration of the period of exposure to sludge. However, during development in utero and neonatal life, the most vulnerable period of development, the ram and ewe lambs of respective treatments were exposed to sludge-treated pastures, or not, in an identical manner. It is noteworthy that the animals exposed for the longer period (ewes) exhibited a lesser treatment difference. Thus, it seems unlikely that the difference in the duration of exposure is the cause of the apparent sex difference in responses. Apparently, the bone tissue is more sensitive in rams than in ewes to pollutants present in sewage sludge. The mechanisms behind this are not known.

Comprehensive quantification of animal exposure to EDCs from sludge is logistically extremely difficult owing to variation in the characteristics of individual pollutants and changing climatic and pasture conditions. However, sludge is known to contain large amounts of a wide range of EDCs (Brunner et al., 1988) and the results of the chemical analysis in the present study (Table 2) indicate that application to land might result in some increase in the soil concentrations of selected EDCs, suggesting that animal exposure was likely to be increased. Since sludge contains a large number of EDCs of different classes and with different mechanisms of action, it is not possible to identify the agent(s) responsible for the observed effects on bone tissues. However, previous studies have shown that bone tissue homeostasis can be perturbed by exposure to either mixtures of EDCs in wildlife species (Fox et al., 2008; Lind et al., 2003; Lind et al., 2004; Sonne et al., 2004) or humans (Alveblom et al., 2003; Glynn et al., 2000; Hodgson et al., 2008) or single compound studies in laboratory (Hermsen et al., 2008; Jamsa et al., 2001; Lind et al., 1999; Lind et al., 2000a) or domestic animals (Lundberg et al., 2006).

For the male animals, the absence of differences between $\mathrm{T}$ and $C$ animals in plasma concentrations of the bone markers (BAP, CTX, and 25-OH D) on the day of slaughter can be explained by the long period of time between exposure to EDCs and measurement of the effect or by the fact that bone homeostasis was already stable at this stage. Clearly, the absence of treatment differences in ewes cannot be explained by the absence of exposure to sludge since they were exposed until slaughter. There are at least two possible explanations. Firstly, it is possible that the degree of exposure had declined by the time of slaughter, as a result of loss of pollutant from the sludge to the atmosphere and to the soil so that any changes in marker expression which may have been induced were reduced accordingly. Alternatively, the physiological processes responsible for the altered bone structure may have been active only at earlier stages of development, in which case alteration of bone marker expression would not be expected at later times.

The consequences of the observed effects, from animal and human health perspectives, are difficult to assess. However, the fact that quantifiable changes in bone tissue were detected in sheep grazing pastures fertilized with sewage sludge is of concern because any deviation from the normal development must be regarded as sign that exposure, even to low concentrations of a mixture of environmental pollutants, may interfere with normal physiological processes.

\section{Acknowledgements}

This study was supported by the Scottish Government Rural Environment Research and Analysis Directorate and The Swedish Research Council for Environment, Agricultural Sciences and Spatial Planning (FORMAS).

\section{R E F E R E N C E S}

Alveblom AK, Rylander L, Johnell O, Hagmar L. Incidence of hospitalized osteoporotic fractures in cohorts with high dietary intake of persistent organochlorine compounds. Int Arch Occup Environ Health 2003;76:246-8.

Andrews JE. Polychlorinated biphenyl (Aroclor 1254) induced changes in femur morphometry calcium metabolism and nephrotoxicity. Toxicology 1989;57:83-96.

Brunner PH, Capri S, Marcomini A, Giger W. Occurrence and behaviour of linear alkylbenzenesulphonates, nonylphenol, nonylphenol mono- and nonylphenol diethoxylates in sewage and sewage sludge treatment. Water Res 1988;22:1465-72.

Erhard HW, Rhind SM. Prenatal and postnatal exposure to environmental pollutants in sewage sludge alters emotional reactivity and exploratory behaviour in sheep. Sci Total Environ 2004;332:101-8.

Fowler PA, Dora NJ, McFerran H, Amezaga MR, Miller DW, Lea RG, et al. In utero exposure to low doses of environmental pollutants disrupts fetal ovarian development in sheep. Mol Hum Reprod 2008;14:269-80.

Fox GA, Lundberg R, Wejheden C, Lind L, Larsson S, Orberg J, et al. Health of herring gulls (Larus argentatus) in relation to breeding location in the early 1990s. III. Effects on the bone tissue. J Toxicol Environ Health A 2008;71:1448-56.

Fries GF, Marrow GS. Distribution of hexachlorobenzene residues in beef steers. J Anim Sci 1977;45:1160-5.

Gasser JA. Bone measurements by peripheral quantitative computed tomography in rodents. In: H.HM, H. RS, editor. Methods in molecular medicine: bone research protocols, vol. 80. New Jersey: Humana Press Inc; 2003. p. 323-41.

Ghanem A, Bados P, Estaun AR, de Alencastro LF, Taibi S, Einhorn J, et al. Concentrations and specific loads of glyphosate, diuron, atrazine, nonylphenol and metabolites thereof in French urban sewage sludge. Chemosphere 2007;69:1368-73.

Giger W, Brunner PH, Schaffner C. 4-Nonylphenol in sewage sludge: accumulation of toxic metabolites from nonionic surfactants. Science 1984;225:623-5. 
Glynn AW, Michaelsson K, Lind PM, Wolk A, Aune M, Atuma S, et al. Organochlorines and bone mineral density in Swedish men from the general population. Osteoporos Int 2000;11:1036-42.

Hermsen SA, Larsson S, Arima A, Muneoka A, Ihara T, Sumida H, et al. In utero and lactational exposure to 2,3,7, 8-tetrachlorodibenzo-p-dioxin (TCDD) affects bone tissue in rhesus monkeys. Toxicology 2008;253:147-52.

Hodgson S, Thomas L, Fattore E, Lind PM, Alfven T, Hellström L, et al. PCB exposure and bone mineral density in a general population sample. Environ Health Perspect 2008;116:1162-6.

Ieh. IEH assessment of the ecological significance of endocrine disruption: Effects on reproductive function and consequences for natural populations (assessment A4), Leicester, UK, MRC Institute for Environment and Health. In: Health. IfEa, editor. MRC Institute for Environment and Health., IEH, 1999 IEH assessment of the ecological significance of endocrine disruption: Effects on reproductive function and consequences for natural populations (assessment A4), Leicester, UK, MRC Institute for Environment and Health., 1999.

Jamsa T, Viluksela M, Tuomisto JT, Tuomisto J, Tuukkanen J. Effects of 2,3,7,8-tetrachlorodibenzo-p-dioxin on bone in two rat strains with different aryl hydrocarbon receptor structures. J Bone Miner Res 2001;16:1812-20.

Lind PM, Bergman A, Olsson M, Orberg J. Bone mineral density in male Baltic grey seal (Halichoerus grypus). Ambio 2003;32:385-8.

Lind PM, Eriksen EF, Sahlin L, Edlund M, Orberg J. Effects of the antiestrogenic environmental pollutant 3,3',4,4', 5-pentachlorobiphenyl (PCB \#126) in rat bone and uterus: diverging effects in ovariectomized and intact animals. Toxicol Appl Pharmacol 1999;154:236-44.

Lind PM, Larsson S, Johansson S, Melhus H, Wikstrom M, Lindhe O, et al. Bone tissue composition, dimensions and strength in female rats given an increased dietary level of vitamin $\mathrm{A}$ or exposed to 3,3',4, 4',5-pentachlorobiphenyl (PCB126) alone or in combination with vitamin C. Toxicology 2000a;151:11-23.

Lind PM, Larsson S, Oxlund H, Hakansson H, Nyberg K, Eklund T, et al. Change of bone tissue composition and impaired bone strength in rats exposed to 3,3',4,4',5-pentachlorobiphenyl (PCB126). Toxicology 2000b;150:41-51.

Lind PM, Milnes MR, Lundberg R, Bermudez D, Orberg JA, Guillette Jr LJ. Abnormal bone composition in female juvenile American alligators from a pesticide-polluted lake (Lake Apopka, Florida). Environ Health Perspect 2004;112:359-62.

Lundberg R, Lyche JL, Ropstad E, Aleksandersen M, Ronn M, Skaare JU, et al. Perinatal exposure to PCB 153, but not PCB 126, alters bone tissue composition in female goat offspring. Toxicology 2006;228:33-40.

Miettinen HM, Pulkkinen P, Jamsa T, Koistinen J, Simanainen U, Tuomisto J, et al. Effects of in utero and lactational TCDD exposure on bone development in differentially sensitive rat lines. Toxicol Sci 2005;85:1003-12.
Paul C, Rhind SM, Kyle CE, Scott H, McKinnell C, Sharpe RM. Cellular and hormonal disruption of fetal testis development in sheep reared on pasture treated with sewage sludge. Environ Health Perspect 2005;113:1580-7.

Rhind SM. Are endocrine disrupting compounds a threat to farm animal health, welfare and productivity? Reprod Domest Anim 2005;40:282-90.

Rhind SM. Endocrine disruptors and other food-contaminating environmental pollutants as risk factors in animal reproduction. Reprod Domest Anim 2008;43(Suppl 2):15-22.

Rhind SM, Kyle CE, Mackie C, Telfer G. Effects of exposure of ewes to sewage sludge-treated pasture on phthalate and alkyl phenol concentrations in their milk. Sci Total Environ 2007;383:70-80.

Rhind SM, Kyle CE, Owen J. Accumulation of potentially toxic metals in the liver tissue of sheep grazed on sewage sludge-treated pastures. Anim. Sci. 2005a;81:107-13.

Rhind SM, Kyle CE, Telfer G, Duff EI, Smith A. Alkyl phenols and diethylhexyl phthalate in tissues of sheep grazing pastures fertilized with sewage sludge or inorganic fertilizer. Environ Health Perspect 2005b;113:447-53.

Rhind SM, Smith A, Kyle CE, Telfer G, Martin G, Duff E. Phthalate and alkyl phenol concentrations in soil following applications of inorganic fertiliser or sewage sludge to pasture and potential rates of ingestion by grazing ruminants. J Environ Monit 2002;4:142-8.

Seeman E. Structural basis of growth-related gain and age-related loss of bone strength. Rheumatology 2008;47:2-8.

Smith SR. Organic pollutants. Agricultural recycling of sewage sludge and the environment. Wallingford, UK: CAB International; 1995.

Smith SR. Organic pollutants. Agricultural recycling of sewage sludge and the environment. Wallingford, UK: CAB International; 1996.

Sonne C, Dietz R, Born EW, Riget FF, Kirkegaard M, Hyldstrup L, et al. Is bone mineral composition disrupted by organochlorines in east Greenland polar bears (Ursus maritimus)? Environ Health Perspect 2004;112:1711-6.

Stevens JL, Northcott GL, Stern GA, Tomy GT, Jones KC. PAHs, PCBs, PCNs, organochlorine pesticides, synthetic musks, and polychlorinated n-alkanes in U.K. sewage sludge: survey results and implications. Environ Sci Technol 2003;37:462-7.

Swanson RL, Bortman ML, O`Connor TP, Stanford HM. Science, policy and the management of sewage materials. The New York City experience. Marine Pollution Bulletin 2004;49:679-87.

Toppari J, Larsen JC, Christiansen P, Giwercman A, Grandjean P, Guillette Jr LJ, et al. Male reproductive health and environmental xenoestrogens. Environ Health Perspect 1996;104(Suppl 4):741-803.

Yilmaz B, Seyran AD, Sandal S, Aydin M, Colakoglu N, Kocer M, et al. Modulatory effects of Aroclors 1221 and 1254 on bone turnover and vertebral histology in intact and ovariectomized rats. Toxicol Lett 2006;166:276-84. 